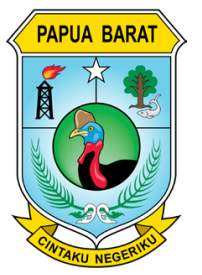

IGYA SER HANJOP 3(1) (2021): 1-13

IGYA SER HANJOP

p-ISSN: 2716-0491

e-ISSN: 2722-516X

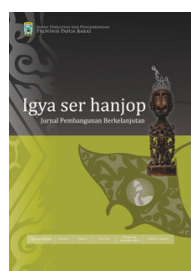

\title{
KERAGAMAN JENIS ANGgREK EPIFIT \\ di Pulau Middleburg Papua Barat
}

\author{
EPIPHYTIC ORCHIDS DIVERSITY \\ IN MidDLEBURg ISLAND West PAPUA
}

\author{
Yasper Michael Mambrasar ${ }^{1 *}$, I Putu Gede P. Damayanto ${ }^{2}$, \\ Indira Riastiwi ${ }^{3}$, Kusuma Rahmawati ${ }^{4}$ \\ ${ }_{1,2,3,4}$ Pusat Penelitian Biologi, Lembaga Ilmu Pengetahuan Indonesia (LIPI). \\ Jl. Raya Jakarta-Bogor km 46, Cibinong, Bogor, Jawa Barat 16911
}

Dikirim: 17 Oktober 2020; Disetujui: 11 Mei 2021; Diterbitkan: 20 Juni 2021

DOI: $10.47039 /$ ish.3.2021.1-13

\begin{abstract}
Inti Sari
Pulau Middleburg merupakan gugusan Pulau Miosu di Papua Barat yang termasuk ke dalam pulau-pulau kecil terluar Indonesia. Informasi keanekaragaman flora, terutama anggrek epifit, di pulau ini belum terekam dengan baik. Tujuan penelitian ini adalah menyediakan informasi keanekaragaman jenis anggrek epifit di Pulau Middleburg. Penelitian menggunakan metode pengumpulan data taksonomi. Material tumbuhan dikoleksi untuk dibuatkan spesimen herbarium dan disimpan di Herbarium Bogoriense (BO). Identifikasi spesimen dilakukan menggunakan acuan spesimen BO dan beberapa pustaka terkait. Dalam penelitian ini dijumpai 10 jenis anggrek epifit di Pulau Middleburg, yaitu Bulbophyllum entomonopsis, Dendrobium bifalce, D. convolutum, $D$. kirchianum, D. litorale, D. mirbelianum, D. smillieae, D. sylvanum, Grammatophyllum scriptum dan Hippeophyllum cf. alboviride.
\end{abstract}

Kata Kunci: anggrek epifit, Papua Barat, Pulau Middleburg.

\begin{abstract}
Middleburg island is a part of Miosu archipelago in West Papua which is the outer small islands of Indonesia. Information on the diversity of flora, especially epiphytic orchids, that has not been recorded properly. This study aims to provide information on the diversity of epiphytic orchids in Middleburg island. The research used taxonomic data collection methods. Plant material was collected for herbarium specimens and stored in Herbarium Bogoriense (BO). Specimen identification using BO specimen and related references. In this study, there are 10 species of epiphytic orchids found on Middleburg island, namely Bulbophyllum entomonopsis, Dendrobium bifalce, D. convolutum, D. kirchianum, D. litorale, D. mirbelianum, D. smillieae, D. sylvanum, Grammatophyllum scriptum dan Hippeophyllum cf. alboviride.
\end{abstract}

Keywords: epiphytic orchid, Middleburg island, West Papua.

\section{Pendahuluan}

Anggrek (Orchidaceae) merupakan salah satu suku tumbuhan berbunga dengan jumlah jenis yang cukup besar, antara 25.000-30.000 jenis (Dressler, 2005; Kartikasari et al., 2012; Utteridge dan Bramley, 2014). Anggrek dikenal sebagai tumbuhan kosmopolitan karena dilaporkan tumbuh tersebar di seluruh dunia, kendati keanekaragaman jenis tertinggi berada di kawasan sub-tropis dan tropis, salah satunya di New Guinea (O’Byrne, 1994; Putra \& Kartika, 2013; Schlechter, 1982).

Terdapat setidaknya 2.800 jenis anggrek di New Guinea (A Schuiteman \& de Vogel, 2001), jumlah ini terus bertambah seiring

\footnotetext{
* Korespondensi Penulis

Tlp : +6282359012267

Email : michaelmambrasar.lipi@gmail.com
}

(C) 2021 Yasper Michael Mambrasar, I Putu Gede P. Damayanto, Indira Riastiwi, Kusuma Rahmawati.

Ciptaan disebarluaskan di bawah Lisensi Creative Common Atribusi NonKomersial-Berbagi Serupa 4.0 Internasional. 
dengan penemuan jenis-jenis anggrek baru di New Guinea. Laporan terkini menyatakan bahwa jumlah jenis anggrek di New Guinea sebanyak 2.869 jenis dan 129 marga (Ormerod, 2017). Potensi menemukan jenis anggrek baru di kawasan ini masih tinggi seperti hasil penelitian lainnya (Juswara et al., 2016; Juswara et al., 2019; Kolanowska \& Nowak, 2019; Lin et al., 2020; Mambrasar \& Schuiteman, 2017; Metsuala, 2019; Nowak et al., 2020; Saputra et al., 2020). Kendati demikian, masih banyak kawasan terpencil di Papua, misalnya pulaupulau kecil terluar di sekitarnya yang belum dieksplorasi atau diteliti.

Pulau-pulau kecil terluar (PPKT) memiliki peran penting bagi Indonesia, yaitu sebagai titik dasar penetapan wilayah perairan Indonesia. Di Indonesia, terdapat 92 pulau yang berstatus sebagai PPKT berdasarkan Peraturan Presiden Nomor 78 tahun 2005. Untuk menghindari aktivitas yang merugikan negara, pemerintah mengeluarkan peraturan tentang pemanfaatan PPKT melalui Peraturan Pemerintah Nomor 62 tahun 2010. Pasal kelima dalam peraturan tersebut menyatakan bahwa PPKT hanya digunakan untuk pertahanan dan keamanan, kesejahteraan masyarakat serta pelestarian lingkungan. Untuk itu, sumber daya alam di PPKT sejatinya dapat dimanfaatkan oleh masyarakat setempat dengan tetap memperhatikan pelestarian lingkungan.

Pulau Middleburg adalah salah satu PPKT yang berada di gugusan Kepulauan Miosu, Kabupaten Tambrauw, Provinsi Papua Barat. Pemerintah atau pemangku kepentingan wajib mewadahi pengelolaan sumber daya alam di Pulau Middleburg agar dapat dimanfaatkan oleh masyarakat sekitar secara bijaksana. Dalam pengelolaan sumber daya alam tersebut, informasi dasar mengenai keanekaragaman jenis flora harus tersedia. Informasi keanekaragaman flora, terutama anggrek epifit, di Pulau Middleburg belum terekam dengan baik. Penelitian ini bertujuan untuk menyediakan informasi keanekaragaman jenis anggrek epifit di Pulau Middleburg. Diharapkan Informasi ini dapat digunakan sebagai data awal dalam pengambilan keputusan terkait pengelolaan Pulau Middleburg sebagai PPKT.

\section{Metode}

Penelitian dilakukan pada bulan Januari 2016 dan Juni 2017 di Pulau Middleburg (Gambar 1). Pulau Middleburg terletak di 13 mil ke arah Timur Laut dari pemukiman Sausapor (Parera et al., 2013) dan dapat ditempuh kurang lebih selama 30 menit dari Kampung Werur, Distrik Bikar atau 1-1,5 jam

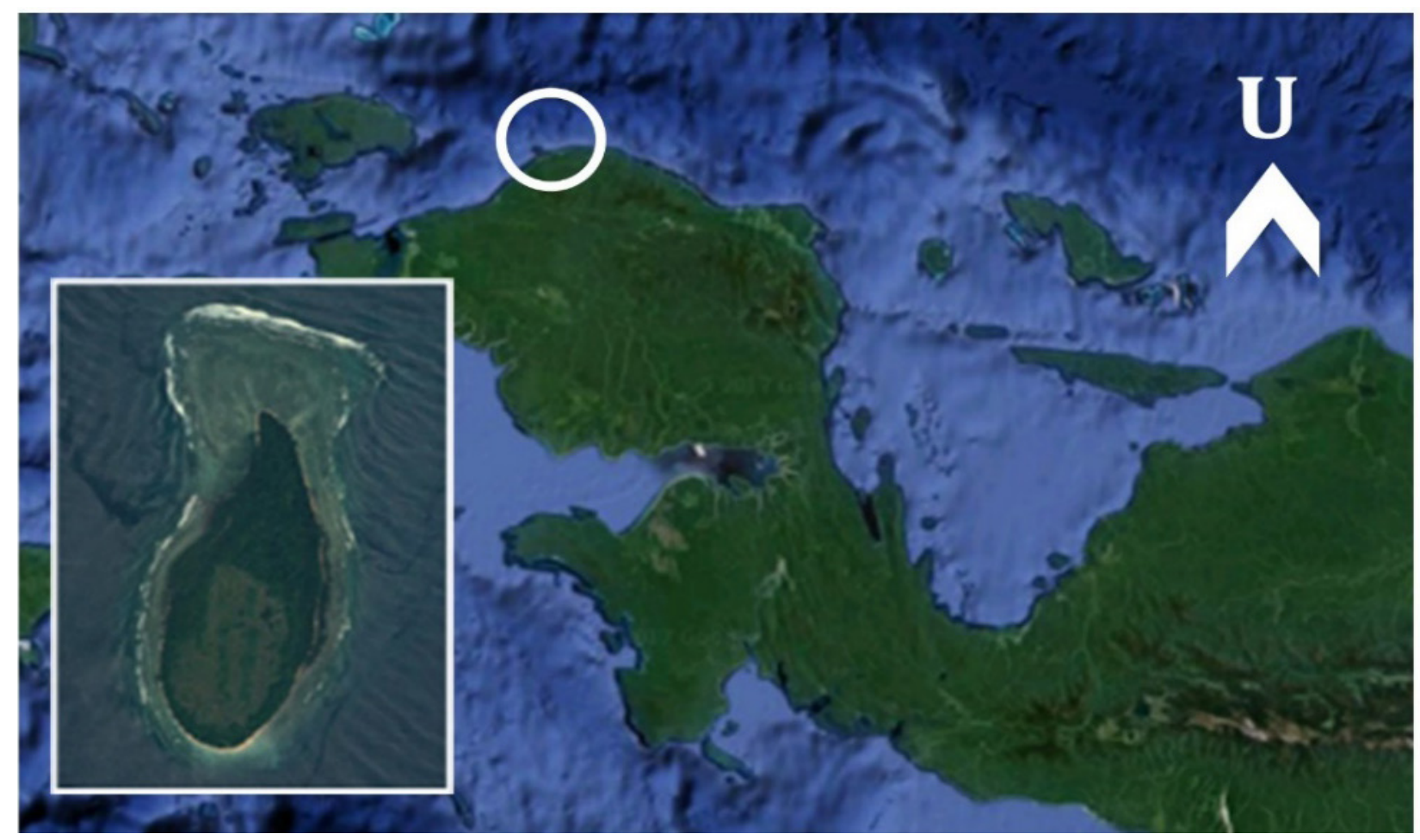

Gambar 1. Lokasi Penelitian di Pulau Middleburg (inset) di atas Kepala Burung Provinsi Papua Barat (Sumber: Modifikasi Google Map, 2020) 
dari Sausapor menggunakan perahu bermesin motor tempel. Secara administratif, Pulau Middleburg termasuk wilayah Kabupaten Tambrauw, Provinsi Papua Barat, Indonesia. Secara geografis, Pulau Middleburg terletak di $0^{\circ} 22^{\prime} \mathrm{LU}$ dan $132^{\circ} 11^{\prime} \mathrm{BT}$, tepat di sebelah Pulau Amsterdam. Kedua pulau ini (Pulau Amsterdam dan Pulau Middleburg) dikenal dengan gugusan Pulau Dua atau Meossu Islands. Masyarakat Sausapor dan Kampung Werur menyebut kedua pulau ini dengan nama "Pulau Besar" untuk Pulau Amsterdam dan "Pulau Kecil" untuk Pulau Middleburg (Oktafiani \& Jogaswara, 2019).

Pulau Middleburg merupakan wilayah yang tidak berpenghuni (Oktafiani \& Jogaswara, 2019) dengan luas sekitar 112 ha (Nugroho et al., 2019) atau $1,3 \mathrm{~km}^{2}$ dan keliling garis pantai sekitar 4.500 m serta ketinggian mencapai 23 $\mathrm{m}$ di atas permukaan laut (dpl) (berdasarkan pengukuran menggunakan Google Earth, 2020). Berdasarkan peta tata ruang Kabupaten Tambrauw, pulau ini termasuk ke dalam kawasan konservasi perairan daerah.

Pengumpulan data dilakukan secara eksplorasi dan koleksi flora menggunakan metode pengumpulan data taksonomi dari Rugayah et al. (2004). Material anggrek epifit dikoleksi dan diberi nomor untuk dibuat spesimen herbarium. Informasi penunjang dicatat seperti lokasi, tanggal koleksi, habitat, ketinggian tempat, nama daerah (jika ada) dan karakter lain yang akan hilang saat spesimen kering (misalnya warna bunga dan adanya lapisan lilin).

Spesimen yang telah dikumpulkan kemudian dibungkus koran dan dimasukkan ke dalam kantong plastik lalu dibasahi dengan alkohol 70\%. Spesimen dikemas dan dikirim ke Herbarium Bogoriense (BO) untuk diproses lebih lanjut mengikuti metode pengolahan herbarium dari Djarwaningsih et al. (2002). Spesimen diidentifikasi dan divalidasi dengan cara mencocokkan dengan spesimen yang tersimpan di BO dan beberapa pustaka terkait (Cribb \& Schuiteman, 2020; L. Juswara et al., 2016; L. S. Juswara et al., 2019; Kolanowska \& Nowak, 2019; Lin et al., 2020; Mambrasar \& Schuiteman, 2017; Metsuala, 2019; Nowak et al., 2020; O’Byrne, 1994; Saputra et al., 2020; Schlechter, 1982; Vermeulen, 1996). Hasil identifikasi dianalisis dan dijabarkan secara deskriptif. Semua spesimen disimpan di BO.

\section{HASIl DAN PEMBahasAN}

Pada bagian ini akan dideskripsikan temuan dan pembahasan mengenai deskripsi dan jenis anggrek serta sebarannya di Pulau Middleburg, Papua Barat.

\section{A. Deskripsi Jenis Anggrek}

Hasil eksplorasi di Pulau Middleburg diperoleh 10 jenis anggrek epifit dari empat marga, yaitu Bulbophyllum entomonopsis J.J.Verm. \& P.O'Byrne, Dendrobium bifalce Lindl., D. convolutum Rolfe, D. kirchianum A.D.Hawkes \& A.H.Heller, D. litorale Schltr., D. mirbelianum Gaudich., D. smillieae F.Muell., D. sylvanum Rchb.f., Grammatophyllum scriptum (L.) Blume dan Hippeophyllum cf. alboviride J.J.Sm. Informasi deskripsi, distribusi, habitat, ekologi dan catatan penting lainnya beserta foto setiap jenisnya disajikan sebagai berikut.

\section{Bulbophyllum entomonopsis J.J.Verm. \& P.O'Byrne}

Bulbophyllum entomonopsis J.J.Verm. \& P.O'Byrne seperti terdapat dalam gambar 2a. Deskripsi: rimpang merayap, pendek, hampir tidak terlihat karena jarak antara umbi semu rapat dan berwarna cokelat. Umbi semu tegak, berdaging dan agak lunak, berwarna hijau kekuningan sampai hijau kusam. Daun tunggal, tegak sampai agak melengkung, berbentuk melonjong sampai lurus, berukuran 9-13 $\times$ 15-25 mm, tipis, berwarna hijau pucat sampai hijau kekuningan dengan permukaan kasar. Bunga muncul pada dasar umbi semu. Bunga tunggal, tegak, sedikit berdaging dan bertangkai pendek; kelopak, bibir dan tugu tampak seperti serangga dengan mata majemuk; sepal menjorong, panjang $\pm 9 \mathrm{~mm}$, berwarna cokelat-krem dengan garis-garis cokelat, petal menjorong, panjang $\pm 3 \mathrm{~mm}$, berwarna putih dengan garis tengah ungu berbulu dan tanda ungu di dekat pangkal; labelum dengan panjang $\pm 3 \mathrm{~mm}$, berwarna putih dengan papila ungu dan dua titik seperti mata pada sisi-sisinya, tugu berwarna hijau dengan bintik-bintik ungu.

Persebaran: anggrek ini dapat dijumpai di Provinsi Gulf dan Central di New Guinea (O’Byrne, 1994). Habitat dan Ekologi: di Pulau Middleburg, anggrek ini tumbuh pada vegetasi mangrove. Secara umum, habitat anggrek ini di hutan atau hutan mangrove pada ketinggian 0-300 m dpl (Vermeulen \& O'Byrne, 1993). 
Catatan: anggrek ini dilaporkan berbunga pada bulan Januari, Februari, Mei hingga Oktober dan juga Desember (Vermeulen \& O'Byrne, 1993). Dalam eksplorasi dijumpai jenis ini berbunga pada bulan Januari dan Juni.

\section{Dendrobium bifalce Lindl}

Dendrobium bifalce Lindl bisa dilihat pada gambar 2. Deskripsi: umbi semu besar, agak melebar ke arah ujung, 11-30 cm × 8-12 mm, kuning, terdiri dari 5-7 ruas mendukung 2-4 daun di ujung. Daun menjangat, agak tegak, jorong hingga lonjong, tumpul, $16 \times 4-6 \mathrm{~cm}$. Perbungaan tegak, muncul dari ketiak daun, panjang 25-40 cm, terdiri dari beberapa sampai banyak kuntum bunga; tangkai perbungaan besar, lebih panjang dari rakis; braktea berdaging, segitiga hingga bundar telur, 2-3 mm panjangnya. Bunga hijau-kuning atau kuning, terdapat tanda merah marun; sepal bagian dorsal kuning, panjang $\pm 7 \mathrm{~mm}$, melonjong-bundar telur; sepal bagian lateral kuning, panjang $\pm 10 \mathrm{~mm}$, melanset; petal kuning, panjang $\pm 7 \mathrm{~mm}$; labelum panjang \pm $13 \mathrm{~mm}$, lobus tengah berwarna kuning sampai kecokelatan.

Persebaran: anggrek ini dapat dijumpai di Pulau Mansinam, Kabupaten Manokwari (Bieth \& Arobaya, 2020) dan wilayah Papua New Guinea seperti Kaiser-Wilhelms-Land, Neu-Pommern, Neu-Lauenburg dan NeuMecklenburg (O’Byrne, 1994), serta di Kepulauan Sunda Kecil, Maluku, Kepulauan Bismarck, Kepulauan Solomon dan Queensland. Habitat dan Ekologi: anggrek ini sangat umum dijumpai di kawasan pesisir pantai sampai ketinggian $800 \mathrm{~m}$ dpl kecuali daerah padang rumput (O'Byrne, 1994).

Catatan: anggrek ini sangat melimpah keberadaannya dan ditemukan berbunga pada Mei, Oktober hingga Desember (Schlechter, 1982). Hasil eksplorasi mendapatkan anggrek jenis ini berbunga pada bulan Januari dan Juni.

\section{Dendrobium convolutum Rolfe}

Dendrobium convolutum Rolfe bisa dilihat pada Gambar 2c. Deskripsi: umbi semu tegak, tinggi 15-28 cm, berwarna kuning atau cokelat kehijauan, bagian bawah umbi semu ramping dan mengembung pada bagian atas. Daun berjumlah 3 (kadang 2), melanset, 13-14 $\times$ 4,5-5 cm, tipis dan kasar, berwarna hijau dan berlekuk. Tangkai perbungaan berjumlah satu atau lebih, tumbuh di ujung atau lateral pada ruas di bagian yang menggelembung, tegak atau terkulai, panjang 9-13 $\mathrm{cm}$ dan mendukung 3-5 kuntum bunga. Bunga bundar telur, sedikit berlilin; sepal bagian dorsal hijau dengan warna cokelat pada bagian dasar, membundar telur, panjang $\pm 15 \mathrm{~mm}$; sepal bagian lateral hijau dengan warna cokelat pada bagian dasar, membundar telur, panjang $\pm 13 \mathrm{~mm}$; petal hijau, bagian dasar cokelat, melanset, panjang $\pm 13 \mathrm{~mm}$; labelum dengan panjang $\pm 14 \mathrm{~mm}$, memiliki urat berwarna merah marun di lobus samping dan merah marun pekat di lobus tengah.

Persebaran: anggrek ini dapat ditemukan di wilayah Papua New Guinea seperti Provinsi Morobe, Madang dan Pulau Karkar (O'Byrne, 1994). Habitatdan Ekologi: di Pulau Middleburg, anggrek ini tumbuh pada mangrove.

Catatan: jenis ini di Papua New Guinea sangat jarang dikoleksi atau dibudidayakan (O'Byrne, 1994). Awalnya, jenis ini digabungkan dengan jenis $D$. bifalce, namun Schlechter (1982) menyatakan bahwa kedua jenis tersebut berbeda. Setelah ditemukan tahun 1906, D. convolutum tidak dtemukan lagi. Hingga pada tahun 1970-an, D. convolutum dikoleksi kembali dari P. Karkar dan lembah Garaina (O'Byrne, 1994). Kini pada 2017 anggrek D. convolutum dikoleksi dari Pulau Middleburg.

\section{Dendrobium kirchianum A.D. Hawkes \& A.H. Heller}

Dendrobium kirchianum A.D. Hawkes \& A.H. Heller bisa dilihat pada gambar $2 d$, dengan deskripsi: rimpang merayap dan bisa tumbuh memanjat, jarang bercabang, diameter $3 \mathrm{~mm}$. Umbi semu 10-12 $\mathrm{mm} \times 4 \mathrm{~mm}$, berbentuk silinder atau menjorong, umbi semu awalnya berkulit halus dan setelah dewasa keriput, berwarna hijau sering tertutup selaput putih. Daun tunggal, $15 \times 7-10 \mathrm{~mm}$, berbentuk bundar telur sampai lonjong, tipis, kaku dan kasar, berwarna hijau tua. Perbungaan berjumlah 1-2, muncul dari bagian atas umbi semu. Bunga berwarna putih; sepal bagian dorsal putih, tegak, panjang $\pm 10 \mathrm{~mm}$; sepal bagian lateral putih, agak melengkung, panjang $\pm 9 \mathrm{~mm}$; petal putih, agak melengkung, panjang $\pm 10 \mathrm{~mm}$; labelum putih dengan bercak ungu, panjang $\pm 10 \mathrm{~mm}$. 
Persebaran: anggrek ini dapat dijumpai di kawasan New Guinea di Provinsi Gulf (O'Byrne, 1994). Habitat dan Ekologi: jenis ini umumnya dijumpai di hutan rawa-rawa, mangrove dan hutan pantai sampai ketinggian $50 \mathrm{~m} \mathrm{dpl}$ (O’Byrne, 1994). Di Pulau Middleburg, jenis ini ditemukan hidup pada hutan mangrove.

Catatan: Hunt \& Summerhayes (1961) membuat kombinasi nama baru jenis ini menjadi Diplocaulobium kirchianum (Hunt \& Summerhayes, 1961). Kendati demikian, Ormerod (2017) melaporkan Dendrobium kirchianum sebagai nama yang diterima saat ini. Informasi mengenai perubahan nama marga Diplocaulobium dapat dilihat dalam Schuiteman (2011) dan Schuiteman \& Adams (2011).

\section{Dendrobium litorale Schltr}

Dendrobium litorale Schltr bisa dilihat pada Gambar 2e dengan deskripsi: batang padat dan ramping, panjang 25-100 cm, bercabang, berwarna hijau kekuningan, keriput dan akan mengkerut saat kering. Daun berukuran 35-80 × 4-7 mm, seperti jarum, sangat pipih dan tajam, agak tebal, kaku dan kasar, serta berwarna hijau. Tangkai perbungaan memiliki panjang 8-15 cm, terletak di batang bagian atas dengan bunga yang muncul satu atau kadang dua. Bunga terbuka lebar, $12 \times 15$ $\mathrm{mm}$, sepal bagian dorsal tegak, sepal bagian lateral terbuka ke samping, petal menyerong dan melebar. Labelum memiliki 3 lobus, lobus samping tumpul dan lobus tengah memiliki lekukan tengah; sepal bagian dorsal putih dengan garis merah, bentuk seperti segitiga, panjang $\pm 5 \mathrm{~mm}$; sepal bagian lateral putih dengan garis merah, berembang, panjang \pm 5 $\mathrm{mm}$; labelum putih polos dengan panjang \pm 10 $\mathrm{mm}$.

Persebaran: anggrek ini dijumpai di Papua New Guinea seperti wilayah Kaiser-WilhelmsLand (Schlechter, 1982), Provinsi Central, Gulf, Madang, Western dan Milne Bay (O'Byrne, 1994), serta Queensland. Habitat dan Ekologi: anggrek ini tumbuh pada ketinggian sekitar 10-15 m dpl dan diketahui berbunga pada bulan April dan Juli (Schlechter, 1982). Hasil eksplorasi diperoleh bahwa jenis anggrek ini tumbuh di pinggir pantai pada mangrove dan berbunga pada bulan Januari. Jenis ini merupakan salah satu anggrek dataran rendah yang paling melimpah di Papua New Guinea (O’Byrne, 1994).

\section{Dendrobium mirbelianum Gaudich}

Dendrobium mirbelianum Gaudich bisa dilihat pada Gambar 3a dengan deskripsi: umbi semu tegak, tinggi $20-30 \mathrm{~cm}$, bagian tengah menggelembung dan ujung meruncing. Daun terdapat pada bagian atas umbi semu, berjumlah 4-10 helai berbentuk bundar telur sampai menjorong, tebal, kaku, kasar dan berwarna hijau. Perbungaan terdiri dari satu atau lebih, muncul di ujung atau lateral pada ruas umbi semu, panjang hingga $35 \mathrm{~cm}$ dan mendukung hingga 20 kuntum bunga. Bunga berwarna kuning kehijauan, sering agak merah atau samar-samar bergaris cokelat; sepal bagian dorsal kuning kehijauan, seperti pedang, panjang $\pm 19 \mathrm{~mm}$; sepal bagian lateral kuning kehijauan, memita, panjang $\pm 21 \mathrm{~mm}$; petal kuning kehijauan, memita, panjang $\pm 27 \mathrm{~mm}$; labelum putih sampai kuning-krem dengan alur seperti urat yang berwarna marun-ungu, panjang $\pm 23 \mathrm{~mm}$.

Persebaran: anggrek ini dapat dijumpai di P. Mansinam, Kabupaten Manokwari (Bieth \& Arobaya, 2020), Taman Wisata Alam Sorong, Kota Sorong, Papua Barat (Saputra et al., 2018) dan kawasan New Guinea seperti Provinsi New Ireland, West Sepik, East Sepik, Central (O’Byrne, 1994) dan Kaiser-WilhelmsLand (Schlechter, 1982), serta Maluku, Sulawesi, Kepulauan Bismarck, P. Solomon dan Queensland. Habitat dan Ekologi: anggrek ini tumbuh di hutan pinggiran pantai, hutan rawa, hutan mangrove maupun di bebatuan dan dapat di temukan pada ketinggian hingga 650 m dpl (O'Byrne, 1994). Jenis ini berbunga pada bulan Juli (Schlechter, 1982), dalam eksplorasi ini ditemukan berbunga pada bulan Januari.

\section{Dendrobium smillieae F. Muell}

Dendrobium smillieae F. Muell bisa dilihat pada Gambar 3b dengan deskripsi: umbi semu bergerombol, tegak, silindris, meruncing pada ujungnya, berdaging, semakin tua menjadi semakin beralur, $25-65 \mathrm{~cm} \times 12-17 \mathrm{~mm}$, ruas panjangnya $2,5-3,5 \mathrm{~cm}$, ruas di bagian atas umbi semu lebih pendek. Pelepah daun berbentuk tabung, sama panjangnya dengan ruas umbi semu. Daun melanset, 6-14 × 2-4 cm, ujung runcing. Perbungaan muncul di lateral pada 


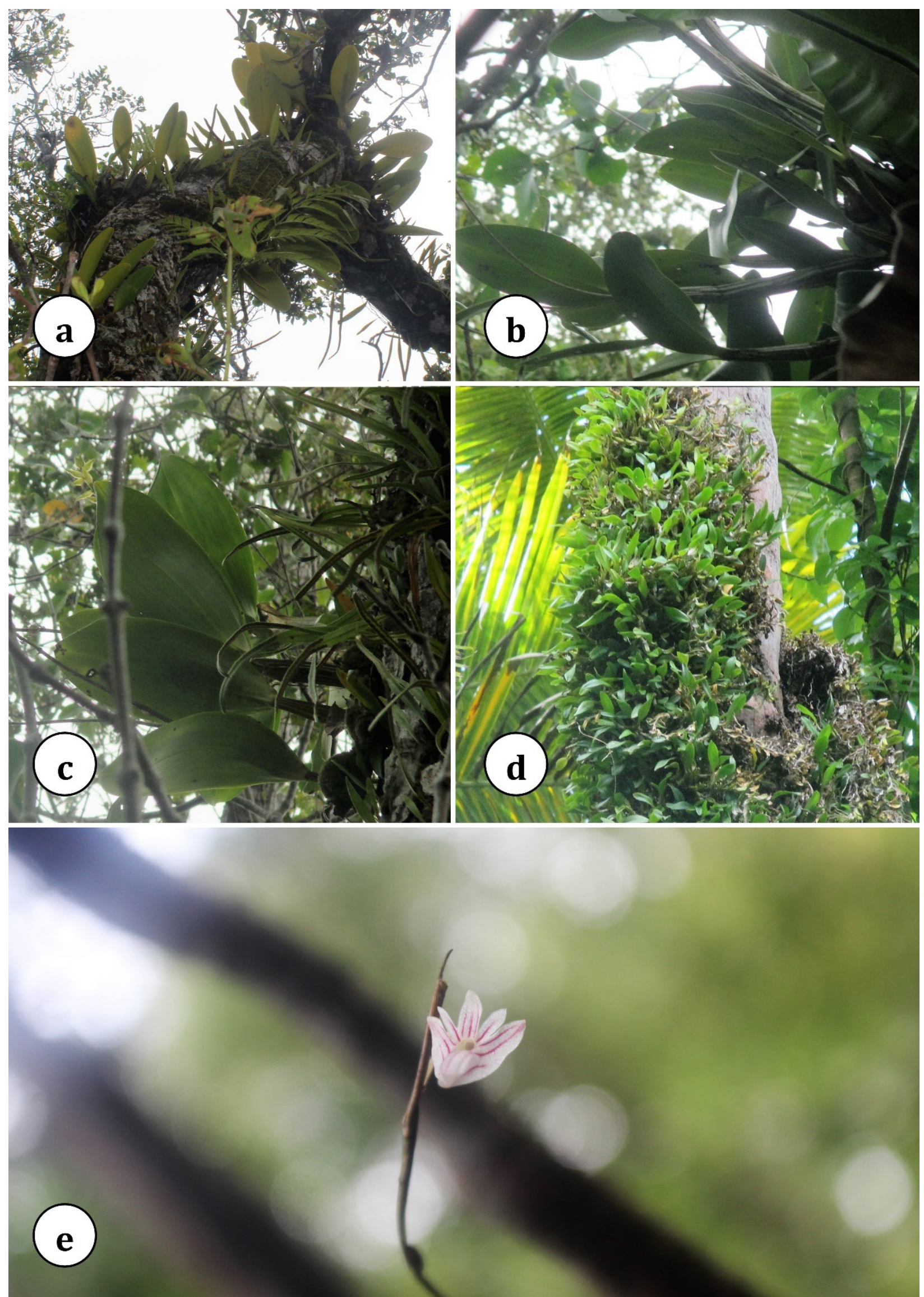

Gambar 2. (a) Bulbophyllum entomonopsis; (b) Dendrobium bifalce; (c) Dendrobium convolutum, (d) Dendrobium kirchianum; (e) Dendrobium litorale (Foto: Yasper Michael Mambrasar) 
umbi semu yang tidak berdaun, berbentuk tandan, panjang 6-7 $\mathrm{cm}$; tangkai perbungaan dengan panjang $\pm 8 \mathrm{~mm}$, mendukung banyak bunga yang padat. Bunga berbentuk tabung, panjang 14-17 mm, berwarna merah jambu; sepal bagian dorsal putih dengan ujung hijau, membundar telur sungsang, panjang $\pm 12 \mathrm{~mm}$; sepal bagian lateral putih dengan ujung hijau, membundar telur, panjang $\pm 5 \mathrm{~mm}$; labelum putih dengan ujung hijau, panjang $\pm 14 \mathrm{~mm}$.

Persebaran: anggrek ini dijumpai di Pulau Salawati (Duwit et al., 2002), serta Taman Wisata Alam Sorong, Kota Sorong, Papua Barat (Saputra et al., 2018). Di kawasan New Guinea, ditemukan di Provinsi Gulf, Central, Madang dan Milne Bay (O’Byrne, 1994), juga dijumpai di Kepulauan Bismarck dan Queensland. Habitat dan Ekologi: anggrek ini tumbuh di hutan hujan dataran rendah dan hutan pantai pada ketinggian 0-450 m dpl (O'Byrne, 1994) dan berbunga pada bulan Januari. Catatan: keberadaan anggrek ini kurang umum di pesisir utara dan kepulauan-kepulauan di wilayah Papua (O’Byrne, 1994).

\section{Dendrobium sylvanum Rchb.f}

Dendrobium sylvanum Rchb.f bisa dilihat pada Gambar 3c dengan deskripsi: umbi semu tegak, tinggi $50-130 \mathrm{~cm}$ dan beruas-ruas. Daun berbentuk bundar telur sampai lonjong dengan ukuran 6-12 × 3-5 cm, tersusun berseling, kaku, tebal, berwarna hijau, ujung daun tumpul. Perbungaan satu atau lebih, tumbuh di lateral dekat ujung umbi semu, panjang 20-40 $\mathrm{cm}$ dan mendukung lebih dari 40 kuntum bunga per tangkai. Bunga berwarna kuning kehijauan; sepal bagian dorsal kuning kehijauan, melonjong, panjang $\pm 23 \mathrm{~mm}$; sepal bagian lateral kuning kehijauan, melonjong, panjang $\pm 22 \mathrm{~mm}$; petal kuning kehijauan, agak melengkung, panjang $\pm 6 \mathrm{~mm}$; labelum hijau dengan garis cokelat, panjang $\pm 25 \mathrm{~mm}$.

Persebaran: anggrek ini dapat dijumpai kawasan Papua New Guinea seperti Provinsi New Ireland, East Sepik, Milne Bay dan Pulau Misima (O'Byrne, 1994), serta di Kepulauan Bismarck, Pulau Solomon hingga kawasan New Caledonia. Habitat dan Ekologi: anggrek ini secara umum ditemukan pada hutan pinggiran pantai dan hutan berawa, serta jarang ditemukan pada hutan primer sampai pada ketinggian $80 \mathrm{~m}$ dpl (O’Byrne, 1994). Jenis ini dijumpai pada hutan mangrove dan ditemukan berbunga pada bulan Januari.

\section{Grammatophyllum scriptum (L.) Blume}

Grammatophyllum scriptum (L.) Blume dapat dilihat pada Gambar 3d. Deskripsi: umbi semu tegak, 8-20 × 4-6 cm, berbentuk bundar telur dan sedikit berkerut, berwarna hijau atau kuning kehijauan. Daun berbentuk bundar telur terbalik, tumbuh tegak atau melengkung, dalam dua deret dengan jumlah hingga delapan helai, agak tipis dan kasar. Perbungaan muncul dari dasar umbi semu dewasa, berjumlah satu atau dua, tegak sampai melengkung, dalam satu tangkai terdapat 30-80 kuntum bunga. Bunga berukuran besar berwarna hijau kekuningan atau kuning dengan bercak cokelat; sepal bagian dorsal dan lateral berwarna kuning dengan bercak cokelat, melanset, panjang \pm $30 \mathrm{~mm}$; petal cokelat dengan bercak cokelat, berbentuk seperti sendok, panjang $\pm 32 \mathrm{~mm}$; labelum putih, panjang $\pm 21 \mathrm{~mm}$.

Persebaran: anggrek ini dijumpai di $P$. Mansinam, Kabupaten Manokwari (Bieth \& Arobaya, 2020). Di kawasan Papua New Guinea seperti Kaiser-Wilhelms-Land, Neu-Pommern, Kepulauan Solomon (Schlechter, 1982), Madang dan P. Manus (O’Byrne, 1994). Di luar Papua New Guinea, jenis ini ditemukan di Sulawesi (Hartini \& Aprilianti, 2020) Maluku, P. Solomon, Fiji, Kepulauan Bismarck dan Santa. Habitat dan Ekologi: jenis ini tumbuh sepanjang hutan pantai, di pulau-pulau dan laguna (O'Byrne, 1994). Jenis ini berbunga pada bulan November dan Desember (Schlechter, 1982). Dalam eksplorasi, jenis ini berbunga pada bulan Januari.

\section{Hippeophyllum cf. alboviride J.J.Sm.}

Hippeophyllum cf. alboviride J.J. Sm bisa dilihat pada Gambar 3e. Deskripsi: rimpang berbentuk silinder, merambat dan melengkung, bercabang, berwarna kuning kehijauan dan panjang rimpang antar batang 20-35 mm. Batang tegak sangat pendek, tertutup oleh pelepah daun. Daun 3-8 $0.5 \mathrm{~cm}$; berjumlah 3-5, tegak, pipih, berwarna hijau pucat, berbentuk seperti pisau dengan sedikit melengkung dan sedikit berdaging. Spesimen yang dikoleksi tidak sedang berbunga. Namun berdasarkan O’Byrne (1994), jenis anggrek ini memiliki rangkaian bunga tunggal, terletak di ujung, muncul dari poros daun termuda, horisontal 
sampai tegak, jumlah bunga per tangkai kurang dari 200. Bunga berukuran kecil; sepal bagian dorsal putih, panjang $\pm 2 \mathrm{~mm}$; sepal bagian lateral putih, panjang $\pm 1 \mathrm{~mm}$; labelum kuning, panjang $\pm 1 \mathrm{~mm}$.

Persebaran: anggrek ini dijumpai di kawasan New Guinea seperti Provinsi West New Britain (O’Byrne, 1994). Habitat dan Ekologi: anggrek ini tumbuh di hutan hujan dataran rendah antara 20-100 mdpl (O'Byrne, 1994). Di Pulau Middleburg, jenis ini ditemukan pada habitat mangrove. Jenis ini dikoleksi tanpa adanya bunga sehingga statusnya masih "cf." yang berarti conferatum atau merujuk pada jenis $H$. alboviride.

\section{B. Penyebaran}

Pulau Middleburg merupakan salah satu pulau yang keberadaannya sangat penting bagi Sekutu pada saat Perang Dunia II, karena dijadikan sebagai salah satu pangkalan udara di kawasan Pasifik (Aini, 2018; Maurer, 1983; Sukandar, 2020). Sebelum menjadi pangkalan udara, Pulau Middleburg awalnya merupakan perkebunan kelapa (Cocos nucifera L.) (Davidson, 2009). Pada saat Sekutu menjadikan pulau ini sebagai pangkalan udara, kurang lebih $80 \%$ luasan pulau tergusur untuk fasilitas angkatan udara Sekutu pada saat itu. Hal ini menyebabkan vegetasi asli dari Pulau Middleburg sebagian besar telah hilang dan digantikan oleh padang rumput yang tumbuh pada bekas pangkalan udara. Pada bagian tepi pantai didominasi oleh pohon ketapang (Terminalia catappa L.), bintangur (Calophyllum sp.), kasuari (Casuarina junghuhniana Miq.), urui (Premna serratifolia L.), manggabluda (Ipomoea pes-caprae L.) dan tikar [Pandanus odorifer (Forssk.) Kuntze].

Pada kedua sisi pulau terdapat vegetasi manggrove yang cukup padat dengan luas sekitar 64 ha (Nugroho et al., 2019). Jenisjenis mangrove yang dijumpai antara lain Avicennia sp., Bruguiera gymnorhiza (L.) Lam., Ceriops tagal (Perr.) C.B.Rob., Rhizophora mucronata Poir., $R$. stylosa Griff., Sonneratia alba Sm., Xylocarpus granatum J.Koenig dan $X$. moluccensis (Lam.) M.Roem (Nurdiansah \& Dharmawan, 2021; Nugroho et al., 2019). Jenis C. tagal dilaporkan mendominasi pada zona-zona darat, sementara itu, pada zona terluar ditemukan jenis $S$. alba (Nurdiansah \& Dharmawan, 2021). Mangrove ini di Pulau
Middleburg menjadi rumah bagi ribuan kalong (Pteropus sp.) (Nugroho et al., 2019) dan tumbuhan bernilai ekonomi seperti anggrek. Akan tetapi kesadaran masyarakat sekitar akan upaya konservasi masih kurang. Kecilnya luas pulau dan kurangnya pengawasan merupakan faktor yang menyebabkan pulau ini rentan terhadap kerusakan (Adrianto et al., 2007). Berdasarkan Undang-Undang Nomor 27 Tahun 2007 tentang Wilayah Pesisir dan Pulau-pulau Kecil, Pulau Middleburg termasuk sebagai pulau kecil (dengan luas $\leq 2.000 \mathrm{~km}$ ). Hal ini menjadikan Pulau Middleburg rentan terhadap ancaman kenaikan air laut. Selain itu topografi pulau yang relatif datar menyebabkan risiko perendaman terhadap air laut semakin tinggi (Tahir et al., 2012). Namun demikian, risiko ancaman ini dapat diminimalisasi dengan upaya konservasi terutama kawasan mangrove yang ada di Pulau Middleburg.

Terdapat 10 jenis anggrek epifit yang ditemukan di Pulau Middleburg. Marga yang paling banyak ditemukan jenisnya adalah Dendrobium, yaitu sebanyak tujuh dari total 10 jenis. Marga Dendrobium banyak ditemukan bahkan di wilayah kecil sekalipun sehingga setiap daerah yang dieksplorasi biasanya selalu dijumpai anggota marga ini dalam jumlah yang cukup mendominasi (Schlechter, 1982). Dendrobium dilaporkan memiliki toleransi tinggi terhadap lingkungan dan dapat tumbuh pada berbagai macam inang (Demena et al., 2020), sehingga tidak mengherankan bila marga ini mudah ditemukan di berbagai habitat kawasan konservasi dataran rendah dengan jumlah jenis yang dominan dibandingkan dengan marga lainnya.

Eksplorasi keanekaragaman anggrek oleh Sulistiarini (2008) di Pulau Wawonii, Sulawesi menemukan bahwa Dendrobium menjadi urutan pertama marga dengan jumlah jenis terbanyak (12 jenis dari total 91 jenis) yang ditemukan. Saputra et al. (2018) melaporkan sebanyak 30 jenis Dendrobium mendominasi Taman Wisata Alam Sorong, Papua Barat dari total 84 jenis yang ditemukan. Puspitaningtyas (2007) menemukan bahwa Dendrobium merupakan marga dengan jenis anggrek epifit terbanyak (empat dari 20 jenis yang ditemukan) di Taman Nasional Meru Betiri, Jawa Timur. Dendrobium juga mendominasi (tiga dari enam jenis) hasil eksplorasi anggrek di hutan Pulau Mansinam, Manokwari, Papua 

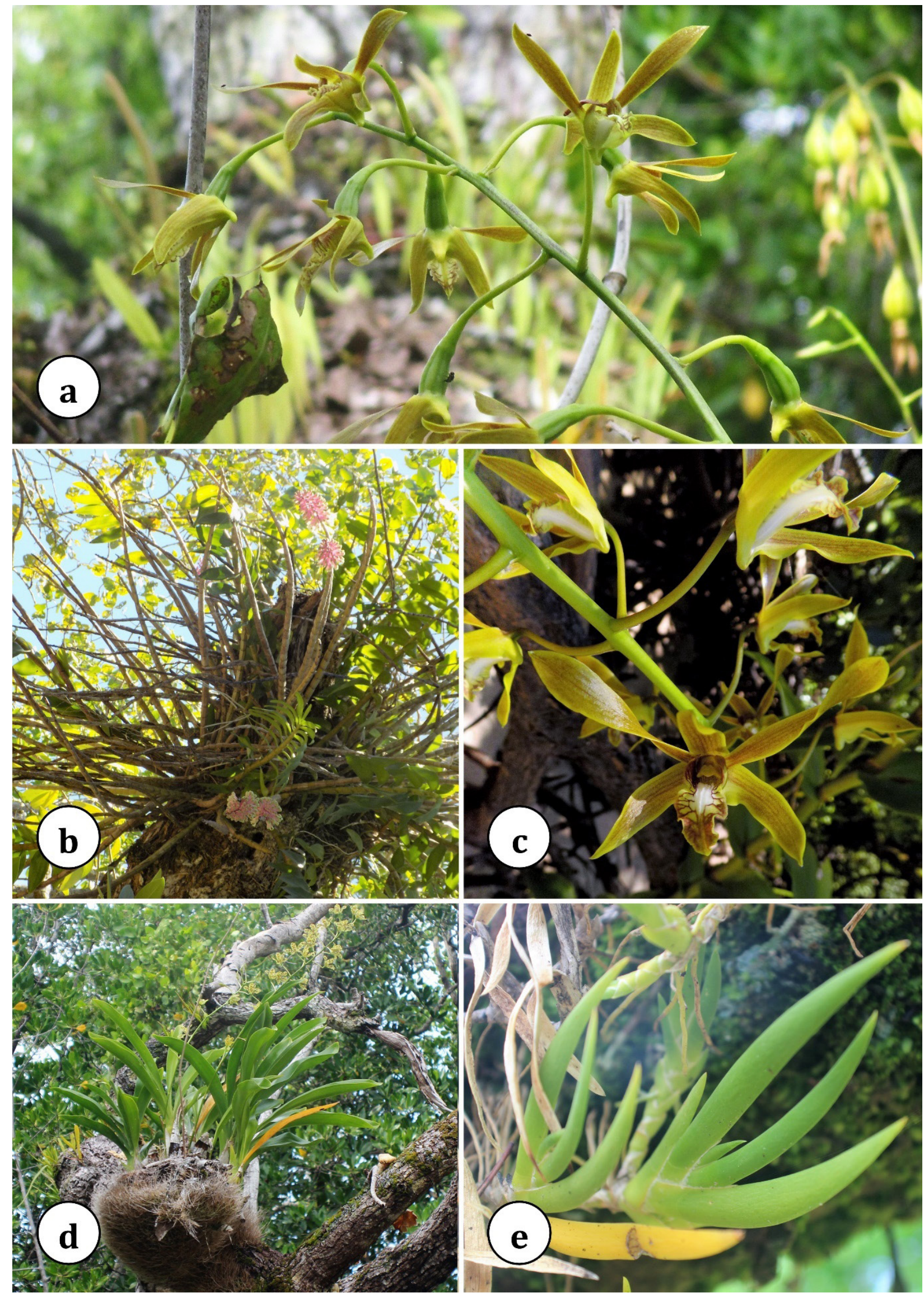

Gambar 3. (a) Dendrobium mirbelianum, (b) Dendrobium smillieae , (c) Dendrobium sylvanum, (d) Grammatophyllum scriptum, (e) Hippeophyllum cf. alboviride. (Foto: Yasper Michael Mambrasar) 


\section{Barat (Bieth \& Arobaya, 2020).}

Jenis anggrek epifit yang ditemukan di Pulau Middleburg merupakan jenis-jenis anggrek yang umumnya ditemukan pada dataran rendah Papua. Dari total 2.869 jenis anggrek yang diketahui tersebar di New Guinea, 269 jenis merupakan jenis-jenis yang umumnya ditemukan di dataran rendah pada ketinggian di bawah $1.000 \mathrm{~m}$ dpl (O'Byrne, 1994). Jenis $G$. scriptum dan $D$. sylvanum merupakan anggrek yang mendominasi di Pulau Middleburg. Berdasarkan pengamatan di lapangan diketahui bahwa faktor yang menyebabkan populasi kedua jenis ini dominan karena kemampuan menghasilkan bunga dan buah. Dari beberapa eksplorasi yang dilakukan, kedua jenis anggrek ini selalu berbunga pada waktu pengamatan di lokasi penelitian, sedangkan jenis yang lain seperti B. entomonopsis, D. convolutum dan D. kirchianum adalah jenis-jenis yang hanya berbunga pada bulan-bulan tertentu.

Jenis-jenis anggrek epifit yang ditemukan di Pulau Middleburg tidak tumbuh tersebar merata di seluruh pulau. Jenis-jenis tersebut hanya ditemukan pada kawasan mangrove yang berada di kedua sisi pulau, terutama di sisi pulau yang berhadapan dengan Pulau Miosu.
Beberapa dari jenis-jenis yang ditemukan tercatat memang mempunyai habitat pada mangrove seperti $B$. entomonopsis, $D$. kirchianum, D. litorale dan D. mirbelianum dan (O'Byrne, 1994).

Semua anggrek epifit yang ditemukan di Pulau Middleburg juga dilaporkan tumbuh secara luas di Papua New Guinea, baik di daratan utama maupun pulau-pulau sekitarnya (O’Byrne, 1994; Schlechter, 1982). Beberapa jenis bahkan dilaporkan ditemukan di luar Papua New Guinea seperti D. mirbelianum dan D. smillieae yang dapat dijumpai tumbuh di Australia sedangkan G. scriptum diketahui tersebar di beberapa wilayah di Indonesia dan Kepulauan di Samudra Pasifik (O’Byrne, 1994).

Anggrek epifit di Pulau Middleburg dipercaya akan tetap lestari bila pemerintah Kabupaten Tambrauw membiarkan pulau ini menjadi wilayah yang tidak berpenghuni. Pertumbuhan penduduk dan alih fungsi hutan sebagai kawasan pemukiman merupakan ancaman bagi keanekaragaman flora dan fauna di daerah pesisir Tambrauw pada saat ini (Nugroho et al., 2019). Namun demikian, melihat banyaknya artefak arkeologi di Pulau Middleburg dan sekitarnya (Aini,

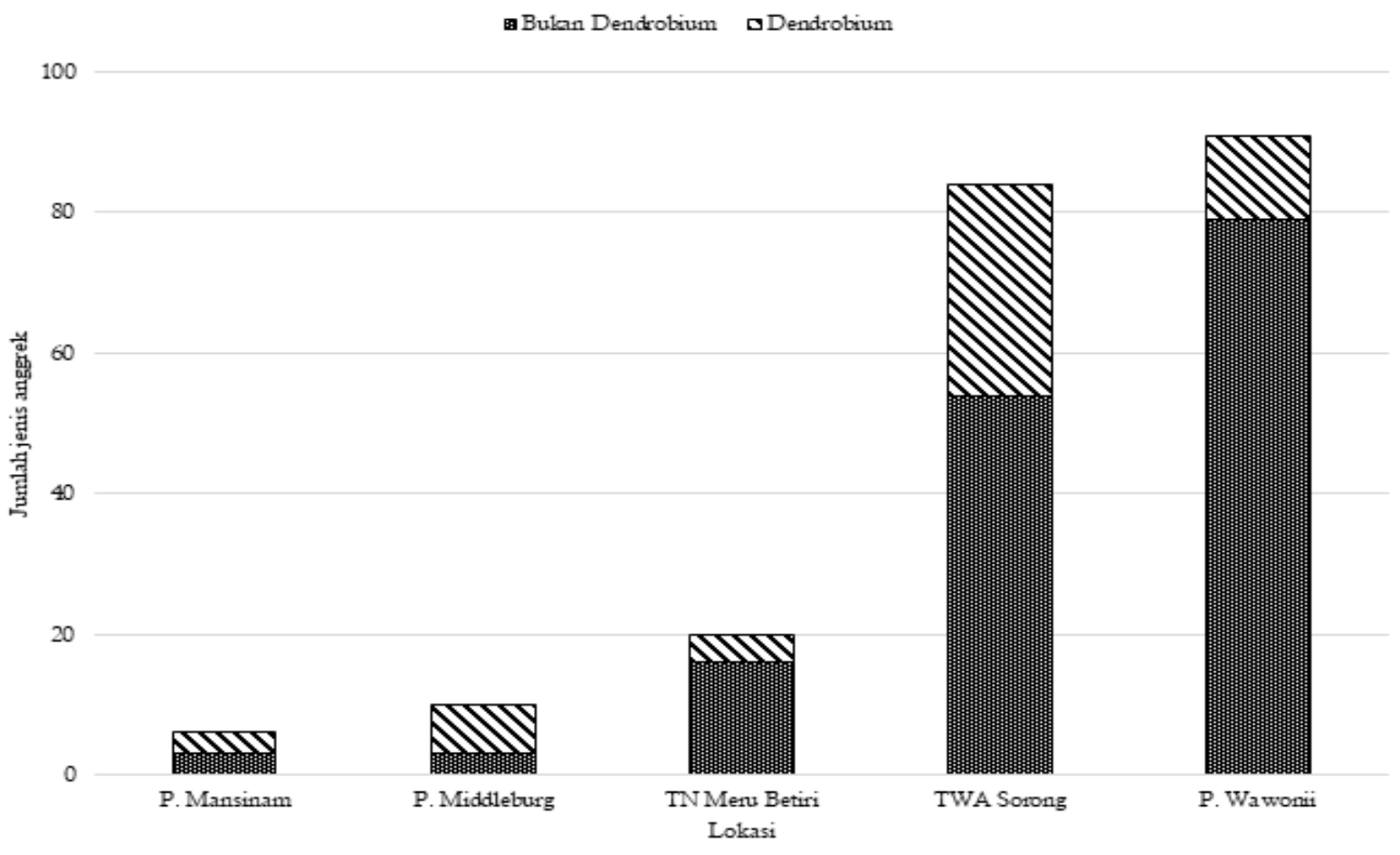

Gambar 4. Perbandingan Jumlah Jenis Anggrek pada Beberapa Kawasan di Indonesia. Keterangan: $\mathrm{P}=$ Pulau, TN = taman nasional, TWA = taman wisata alam. [Sumber: Sulistiarini (2008), Puspitaningtyas (2007), Saputra et al. (2018), Bieth \& Arobaya, (2020)] 
2018; Sukandar, 2020), maka diharapkan pengembangan potensi wisata sejarah dapat menjadi alternatif peningkatan ekonomi penduduk setempat. Peran pemerintah sangat dibutuhkan untuk dapat bersinergi dengan penduduk setempat untuk mengelola keanekaragaman flora dan fauna Pulau Middleburg. Selanjutnya, inventarisasi jenis-jenis anggrek di Pulau Amsterdam perlu dilakukan untuk melengkapi data keanekaragaman anggrek di Pulau Middleburg.

\section{KESIMPULAN}

Studi ini menemukan 10 jenis anggrek epifit yang tumbuh alami di Pulau Middleburg, yaitu Bulbophyllum entomonopsis, Dendrobium bifalce, $D$. convolutum, D. kirchianum, D. litorale, $D$. mirbelianum, D. smillieae, D. sylvanum, Grammatophyllum scriptum dan Hippeophyllum cf. alboviride.

\section{UCAPAN TERIMA KASIH}

Penulis mengucapkan terima kasih kepada Kepala Pusat Penelitian Biologi - LIPI dan Kepala Herbarium Bogoriense (BO) atas fasilitas yang diberikan selama melakukan penelitian. Terima kasih kami ucapkan kepada Dra. Diah Sulistiarini M.S. (BO) yang telah bersedia meninjau dan memberikan masukan dalam tulisan ini. Terima kasih juga kepada Badan Penelitian dan Pengembangan Daerah Provinsi Papua Barat, khususnya redaksi Jurnal Igya Ser Hanjop atas kesempatan penerbitan naskah ini, serta para reviewer anonim yang sudah memberikan saran revisi naskah ini.

\section{Daftar Pustaka}

Adrianto, L., Eidman, E., \& Adiyanto, E. (2007). Tinjauan Hukum dan Kebijakan Pengelolaan Pulau-Pulau Kecil Terluar Indonesia (Studi Kasus Pulau Nipa) - Neliti. Buletin Ekonomi Perikanan, 7(2), 51-62.

Aini, N. (2018). Sisa Perang Dunia II Bertebaran di Hutan Papua. Republika.Co.Id. https:// www.republika.co.id/berita/phajr2382/ sisa-perang-dunia-ii-bertebaran-di-hutanpapua

Bieth, N. R., \& Arobaya, A. Y. S. (2020). Exploration and Identification of Orchid Species Around Mansinam Island Forest of Manokwari. Jurnal Kehutanan Papuasia, 6(1), 106-112. https://doi.org/10.46703/ jurnalpapuasia.Vol6.Iss1.202

Cribb, P., \& Schuiteman, A. (2020). Bulbophyllum Ankylochele. Curtis's Botanical Magazine, 37(2), 155-163. https://doi.org/10.1111/ curt.12330

Davidson, P. D. (2009). Bulldozing The Way: New Guinea To Japan (Second Edition). Lulu.

Demena, M., Raunsay, E. K., \& Agustini, V. (2020). Karakter Habitat Jenis-Jenis Anggrek Epifit dan Terestrial di Hutan Kampung Kantumilena Distrik Yokari Kabupaten Jayapura. Jurnal Kehutanan Papuasia, 6(1), 62-70. https://doi.org/10.46703/ jurnalpapuasia.vol6.iss1.198

Djarwaningsih, T., Sunarti, S., \& Kramadibrata, K. (2002). Panduan Pengolahan dan Pengelolaan Material Herbarium serta Pengendalian Hama terpadu di Herbarium Bogoriense.

Doni Nurdiansah, \& I Wayan Eka Dharmawan. (2021). Struktur Komunitas dan Kondisi Kesehatan Mangrove di Pulau MiddleburgMiossu, Papua Barat. Jurnal Ilmu Dan Teknologi Kelautan Tropis, 13(1), 8196. https://doi.org/10.29244/jitkt. v13i1.34484

Dressler, R. L. (2005). How Many Orchid Species? Proceedings of the Second International Orchid Conservation Congress, 155-158. https://www.jstor. org/stable/41760186? seq =1

Duwit, N., Arwam, C. Y. H., \& Manusawai, J. (2002). Identifikasi Jenis Anggrek Epifit pada Kawasan Hutan Mangrove Desa Waijan Kecamatan Samate Kabupaten Sorong (Epiphyte Orchids From Mangrove Forest in Waijan Village-Sorong Regency). Beccariana: Botanical Research Bulletin, 4(1), 41-48.

Hartini, S., \& Aprilianti, P. (2020). Orchid Exploration in Tanjung Peropa Wildlife Reserves for Kendari Botanic Gardens Collection, Indonesia. Biodiversitas Journal of Biological Diversity, 21(5), 2244-2250. https://doi.org/10.13057/biodiv/ d210554

Hunt, P. F., \& Summerhayes, V. S. (1961). Notes on Asiatic Orchids III. Taxon, 10(4), 101110. https://doi.org/10.2307/1217855

Juswara, L. S., Schuiteman, A., \& Champion, 
J. (2019). Dendrobium Annulatum (Orchidaceae: Epidendroideae), a New Species of Dendrobium section Grastidium from Indonesian New Guinea. Phytotaxa, 414(3), 151-155. https://doi. org/10.11646/phytotaxa.414.3.4

Juswara, L., Schuiteman, A., \& Droissart, V. (2016). Four New Orchid Species from the Lengguru Fold Belt, West Papua, Indonesia. PhytoKeys, 61(1), 47-59. https://doi. org/10.3897/phytokeys.61.7590

Kartikasari, S., Marshall, A., \& Beehler, B. M. (2012). Ekologi Papua. Yayasan Obor Indonesia.

Kolanowska, M., \& Nowak, S. (2019). Hymenorchis papuana (Orchidaceae), a New Species from Papua New Guinea. Annales Botanici Fennici, 56(4-6), 235. https://doi.org/10.5735/085.056.0407

Lin, D., Zhou, K., Hidayat, A., \& Jin, X.-H. (2020). Bulbophyllum Papuaense (Orchidaceae), a New Species from Indonesia. PhytoKeys, 138, 125-130. https://doi.org/10.3897/ phytokeys.138.38714

Mambrasar, Y. M., \& Schuiteman, A. (2017). Trichotosia Gabriel-Asemiana (Orchidaceae), A New Species from Tambrauw, West Papua Province, Indonesia. Reinwardtia, 16(2), 107. https://doi.org/10.14203/reinwardtia. v16i2.3310

Maurer, M. (1983). Air Force Combat Units of World War II. https://media.defense. gov/2010/Sep/21/2001330256/-1/1/0/AFD-100921-044.pdf

Metsuala, D. (2019). Dendrobium nagataksaka (Orchidaceae: Epidendroideae), A New Species of Section Spatulata From Papua, Indonesia. Phytotaxa, 415(5), 271-278. https://doi.org/10.11646/ phytotaxa.415.5.3

Nowak, S., Efimov, P., Szlachetko, D. L., \& Kolanowska, M. (2020). The genus Platanthera (Orchidaceae) in New Guinea with Description of Platanthera Valkenburgii. New Zealand Journal of Botany, 58(3), 236-244. https://doi.org/1 0.1080/0028825X.2020.1722184

Nugroho, H., Riyanto, A., Wiantoro, S., Santika, Y., \& Irham, M. (2019). Ekspedisi Tambrauw: Sepotong Surga di Tanah Papua. LIPI Press. O'Byrne, P. (1994). Lowland Orchids of Papua
New Guinea. Singapore.

Oktafiani, I., \& Jogaswara, H. (2019). Migrasi Orang Biak dan Identitas Orang Asli Papua di Sausapor, Papua Barat. Antropologi Indonesia, 40(1), 1-21. https://doi. org/10.7454/ai.v40i1.11278

Ormerod, P. (2017). Checklist of Papuasian Orchids. Nature \& Travel Books.

Parera, A. M. ., Usmany, D. P., Saberia, \& Sinaga, R. (2013). Sausapor Saksi Sejarah Perang Dunia II di Kabupaten Tambrauw Provinsi Papua Barat. Balai Pelestarian Nilai Budaya Yogyakarta. //pustaka.kebudayaan. kemdikbud.go.id/index.php?p=show detail\&id=826\&keywords $=$

Puspitaningtyas, D. M. (2007). Orchid Inventory and the Host in Meru Betiri National Park â€" East Java. Biodiversitas Journal of Biological Diversity, 8(3), 210214. https://doi.org/10.13057/biodiv/ d080309

Putra, G. B. N. P., \& Kartika, I. N. (2013). Analisis Sektor-Sektor Potensial Dalam Menentukan Prioritas Pembangunan di Kabupaten Badung Tahun 20012011. E-Jurnal Ekonomi Pembangunan Universitas Udayana, 2(9), 401-405.

Rugayah, Widjaja, E., \& Praptiwi. (2004). Pengumpulan Data Taksonomi. In Pedoman Pengumpulan Data Keanekaragaman Flora (pp. 5-42). Pusat Penelitian Biologi-LIPI.

Saputra, R., Naive, M. A. K., Wanma, J. F., \& Schuiteman, A. (2020). Dendrobium Moiorum (Orchidaceae: Epidendroideae), a New Species of Dendrobium Section Diplocaulobium from West Papua, Indonesia. Phytotaxa, 430(2), 142146. https://doi.org/10.11646/ phytotaxa.430.2.5

Saputra, R., Tibalia, D., Darwis, F., \& Sumirto, A. (2018). Keanekaragaman Anggrek (Orchidaceae) di Taman Wisata Alam Sorong, Kota Sorong, Papua Barat. JURNAL BIOLOGI PAPUA, 10(2), 74-79. https://doi. org/10.31957/jbp.492

Schlechter, R. (1982). The Orchidaceae of German New Guinea (incorporating the Figure Atlas to the above) (First English). The Australian Orchid Foundation.

Schuiteman, A, \& de Vogel, E. F. (2001). Orchids of New Guinea (Vol I). National Herbarium Nederland. 
Schuiteman, André. (2011). Dendrobium (Orchidaceae): to Split or Not to Split? In The Gardens' bulletin, Singapore. (Vol. 63). Govt. Print. Off. .

Schuiteman, André, \& Adams, P. B. (2011). New combinations in Dendrobium (Orchidaceae). Royal Botanic Garden, 29(1), 62-68.

Sukandar, S. C. (2020). Pulau Abidon: Potensi Arkeologi di kawasan Pulau Terluar Raja Ampat. Naditira Widya, 14(2), 107-120. https://doi.org/10.24832/nw.v14i2.420

Sulistiarini, D. (2008). Keragaman Jenis Anggrek Pulau Wawoni. Berkala Penelitian Hayati, 14(1), 21-27. http://www.berkalahayati. org/index.php/jurnal/article/view/295
Tahir, A., Boer, M., Susilo, S. B., \& Jaya, I. (2012). Indeks Kerentanan Pulau-Pulau Kecil : Kasus Pulau Barrang Lompo-Makasar. Ilmu Kelautan: Indonesian Journal of Marine Sciences, 183-188. https:/ / ejournal.undip. ac.id/index.php/ijms/article/view/1620

Utteridge, T. M. A., \& Bramley, G. (2014). The Kew Tropical Plant Families Identification Handbook. Royal Botanic Gardens.

Vermeulen, J. J. (1996). New species of the genus Bulbophyllum (Orchidaceae) from Sumatra, Borneo, and Papua New Guinea. Blumea: Biodiversity, Evolution and Biogeography of Plants, 41(2), 347-374.

Vermeulen, J. J., \& O’Byrne, P. (1993). Two new species of Bulbophyllum (Orchidaceae) from Papua New Guinea. 38(1), 157-160. 